\title{
Effects of a bloom of Planktothrix rubescens on the fish community of a Spanish reservoir
}

\author{
A. Almodóvar ${ }^{1,2}$, G.G. Nicola ${ }^{1} \&$ M. Nuevo ${ }^{1}$ \\ ${ }^{1}$ Instituto Madrileño de Investigación Agraria y Alimentaria (IMIA), Finca "El Encín”, Apdo. 127, 28800 \\ Alcalá de Henares, Madrid, Spain. ana.almodovar@imia.madrid.org \\ ${ }^{2}$ Departamento Interuniversitario de Ecología, Facultad de Ciencias, Universidad de Alcalá, 28871 Alcalá \\ de Henares, Madrid, Spain.
}

\begin{abstract}
During the spring of 2000 and 2001 there were two cyanobacterial bloom episodes in El Atazar reservoir (central Spain). They were attributed to the toxic cyanobacteria Planktothrix rubescens. The goal of the present study was to determine the possible effects and toxicity of these blooms on the fish community of the reservoir. The main objectives were to analyse the presence and concentration of toxins in fish liver and to carry out histopathological analyses of liver tissue. In addition, recent data on water quality of the reservoir were inspected to ascertain the likely causes of the blooms. The analysis of water quality data and weather conditions showed that there was not a single key cause of the P. rubescens bloom. Toxin analyses showed that microcystins were absent or in very low concentrations in fish liver extracts obtained from the reservoir. This finding should not be considered as definitive since liver pathologies were detected in the fish studied, which were probably due to exposure to hepatotoxins. Histological analyses revealed the occurrence of pigmented macrophage aggregates (MAs) in the liver sections of nearly all fish exposed to the bloom. MAs are known to change in number, size and pigment content in relation to fish health and environmental degradation. The average MAs per specimen showed a great variability among samples, and their distribution within the liver tissue was highly heterogeneous. However, further research is needed to give an insight into the pathogenesis for the cyanobacteria-associated liver pathology.
\end{abstract}

Keywords: Cyanobacterial bloom, freshwater fish, histopathology, microcystins, pigmented macrophage aggregates, Planktothrix rubescens

\section{RESUMEN}

Durante la primavera de 2000 y 2001 se produjeron dos proliferaciones masivas de una cianobacteria tóxica identificada como Planktothrix rubescens en el embalse de El Atazar (centro de España). En el presente estudio se ha realizado una investigación sobre los posibles efectos y toxicidad de esta proliferación en la comunidad de peces del embalse. Los principales objetivos fueron analizar la presencia y concentración de toxinas en muestras de hígado, así como llevar a cabo un análisis histopatológico del tejido hepático. También se analizaron datos recientes sobre la calidad del agua del embalse para detectar los posibles cambios que pudieron desencadenar la proliferación de la cianobacteria. El análisis de la calidad del agua y de las condiciones meteorológicas mostró la existencia de múltiples factores que pudieron influir en las proliferaciones de P. rubescens. En los análisis de las extracciones realizadas a partir de las muestras de hígado de los peces del embalse no se detectaron toxinas o estuvieron presentes en concentraciones muy bajas. Estos resultados no se pueden considerar definitivos, ya que se detectaron afecciones hepáticas en los individuos estudiados que probablemente fueron debidas a la ingestión de toxinas por los peces. La mayor parte de los peces afectados por la proliferación presentaron centros melanomacrofágicos (MAs) en el hígado. El número, tamaño y contenido en pigmentos de los MAs suele depender de la salud del pez y del grado de degradación ambiental. El número medio de MAs presentó una notable variación entre los individuos analizados y su distribución en el hígado fue bastante heterogénea. Sin embargo, se necesita un estudio más detallado para profundizar en los mecanismos que han originado la patología observada.

Palabras clave: Peces continentales, centros melanomacrofágicos, histopatología, microcistinas, Planktothrix rubescens, proliferación de cianobacterias 


\section{INTRODUCTION}

Cyanobacterial blooms occur in response to a combination of climatic and hydrographic events and to the availability of nutrients, trace metals and vitamins (Bruno et al., 1989; Chorus \& Bartram, 1999; Paerl et al., 2001). They are usually caused by an increase of nutrients in water, mainly phosphorus and nitrogen, that favours the growth of cyanobacteria (Smith, 1977; Mason, 1991; Chorus \& Bartram, 1999). Maximum growth rates for cyanobacteria have been observed around $25^{\circ} \mathrm{C}$ (Robarts \& Zohary, 1987). Therefore, these blooms usually take place in eutrophic waters at high temperature.

During the spring of 2000 and 2001 a substantial bloom of Planktothrix rubescens occurred in El Atazar reservoir (central Spain). Blooms of Planktothrix spp. have been previously reported mainly from northern lakes and reservoirs in Europe (e.g. Ostensvik et al., 1981; Leeuwangh et al., 1983; Skulberg et al., 1984; Berg et al., 1986; Lindholm et al., 1989). Cyanobacteria of the genus Planktothrix are capable of producing several potent hepatotoxins (Chorus \& Bartram, 1999), called microcystins (Carmichael, 1992; Skulberg et al., 1993). Bioaccumulation of microcystins in aquatic vertebrates and invertebrates has been formerly reported by Eriksson et al. (1989), Tencalla et al. (1994), Carbis et al. (1994), Vasconcelos (1994, 1995), Beattie et al. (1998) and Thostrup \& Christoffersen (1999). Therefore, high cyanobacteria concentrations in an aquatic system could deteriorate water quality and increase the risk of animal toxicity (Freitas de Magalhaes et al., 2001).

Fish are considered to be appropriate test organisms for the assessment of harmful xenobiotic chemicals as microcystins, because of their systematic position as vertebrates and as an end-point of the aquatic food chain (Baganz et al., 1998). The main pathological effects of microcystins on fish are damage to the gills, skin, heart, kidney, spleen and liver, as well as growth inhibition and mortality (Phillips et al., 1985; Rahbergh et al., 1991; Rodger et al.,
1994; Tencalla et al., 1994). Furthermore, microcystins can also affect embryos (Oberemm et al., 1997) and fish behaviour (Baganz et al., 1998). These damages have been observed both in experimental studies (Gaete et al., 1994; Bury et al., 1996) and field conditions (Eriksson et al., 1986; Rodger et al., 1994). However, previous studies indicate that microcystins act specifically on liver cells (Eriksson et al., 1990; Rahbergh et al., 1991). The exclusive targeting of microcystin toxicity to liver reflects the hepatic accumulation of the toxin, since following dosing of animals with radioactively labelled microcystin derivatives significant amounts of microcystins are only found in this organ (Runnegar et al., 1986,1993; Falconer et al., 1986; Robinson et al., 1991).

The final aim of the present study was to determine the effects and toxicity of the bloom of Planktothrix rubescens on the fish community of El Atazar reservoir located in central Spain. Our main objectives were to analyse the presence and concentration of toxins in fish liver and to carry out histopathological analyses of liver tissue. In addition, recent data on the water quality of the reservoir were inspected to ascertain the likely causes of the blooms.

\section{MATERIAL AND METHODS}

\section{Study area}

The study was conducted in El Atazar reservoir, a deep $(100 \mathrm{~m})$ oligo-mesotrophic water body located in central Spain (UTM: 30TVL458545338) which is fed by the River Lozoya. This river is a tributary of the River Tagus and have soft, infertile waters arising from granite and metamorphic grounds. The reservoir has an area of $10.7 \mathrm{~km}^{2}$ and holds an average of $425 \mathrm{hm}^{3}$ of water, being the largest and most important water supply reservoir of the Madrid city area. The River Madarquillos (UTM: 30TVL451145427) was chosen as a reference site, since it was not affected by the bloom. It is a tributary of the River Lozoya located further upstream of the reservoir. 


\section{Water analyses}

Data on water quality of the reservoir during the spring-summer periods of 2000 and 2001 were analysed. These data are based on weekly analyses made by "Canal de Isabel II", from the Regional Environmental Agency of Madrid. Chemical water parameters were analysed according to American Public Health Association (APHA) (1985). Chlorophyll $a$ was determined by fluorometric analysis. Microcystins were estimated using ELISA assay that is based upon the polyclonal antibody method described by Chu et al. (1990). Microcystin standards were used to construct regression relationships to calculate sample toxin concentration.

\section{Fish sampling}

During June 2001, fish were captured in the reservoir using trammel nets in areas affected by the bloom. Additionally, control fish were collected in the reference site by means of electrofishing using a $220 \mathrm{~W}$ DC generator. A total of 38 specimens were captured, most of which were common barbel Barbus bocagei. There was also one goldfish Carassius auratus and one largemouth bass Micropterus salmoides. Each fish was packed in a plastic bag and frozen immediately after capture on dry ice until analysed in the laboratory. Fish were measured (fork length, to the nearest $\mathrm{mm}$ ), weighted (to the nearest $0.1 \mathrm{~g}$ ) and examined for external lesions or parasites which could be related to the presence of the toxic cyanobacteria in the water. While still partly frozen fish were dissected, and liver samples were collected and preserved for histopathological and toxin analyses. The fish from the affected area mainly consisted of similar-sized barbel (mean length, $40.8 \pm 22.6$ $\mathrm{cm}$; range, 36.5-45.6), whereas in the reference site fish captured were also barbel but smaller (mean length, 10.1 \pm 15.5 ; range, 7.8-11.6).

\section{Histology}

The liver samples were embedded in TissueTec ${ }^{\circledR}$ and frozen in liquid nitrogen. Then, twelve sections of $10 \mu \mathrm{m}$ per specimen were cut with a cold microtome (Cryocut). Sections were stained with haematoxylin and eosin, and mounted for later pathological assessment by light microscopy (Disbrey \& Rack, 1970).

\section{Microcystins analysis}

To analyse toxins in liver tissue, six samples from El Atazar and two from the reference site were extracted twice with $100 \%$ methanol. The

(A)

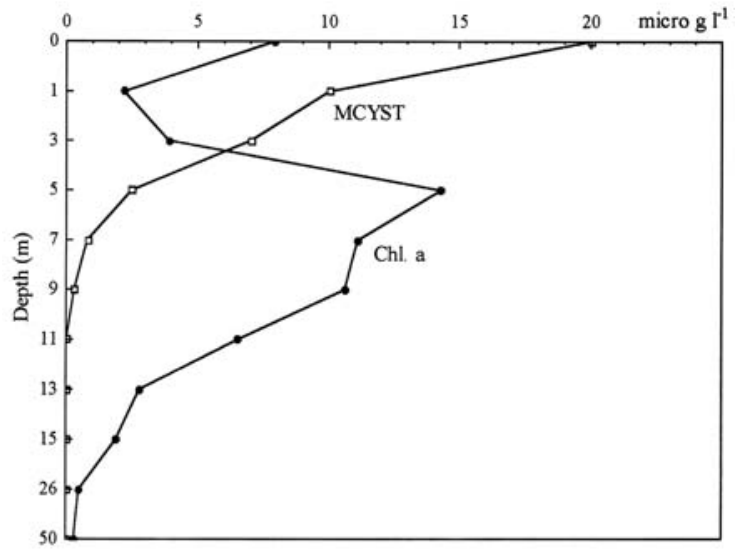

(B)

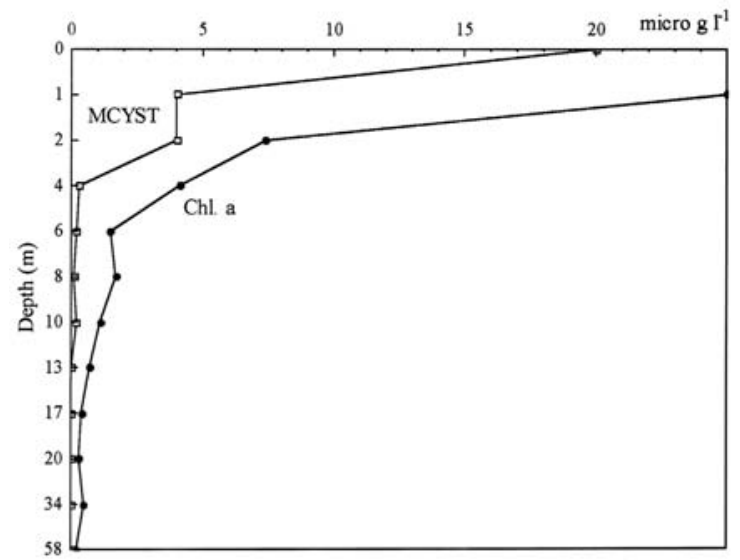

Figure 1. Vertical distribution of chlorophyll $a$ (closed circles) and microcystins (open squares) in El Atazar reservoir during the bloom of P. rubescens in A) June 12000 and B) May 31 2001. Distribución vertical de clorofila a (círculos rellenos) y microcistinas (cuadrados vacios) en el embalse de El Atazar durante la proliferación de $\mathrm{P}$. rubescens en A) 1 de junio de 2000 y B) 31 de mayo de 2001. 
methanol extract was mixed three times with equal volumes of hexane. Hexane layers were discarded and the methanol extract was dried and redissolved in deionized water. This extract was loaded into a $\mathrm{C} 18$ cartridge which was washed and eluted with $30 \mathrm{ml}$ of $20 \%$ methanol and $50 \mathrm{ml}$ of $100 \%$ methanol, respectively. The $100 \%$ methanol fraction was dried and redissolved in $1 \mathrm{ml}$ of $100 \%$ methanol:water $(1: 1$ $\mathrm{v} / \mathrm{v})$. Analyses for microcystin detection were performed by HPLC with a Lichrospher 100 RP-18 reverse phase column ( $5 \mu \mathrm{m}$-Merck). Chromatography was carried out under isocratic conditions with a mobile phase of $20 \mathrm{~mm}$ ammonium acetate, $\mathrm{pH} 5.0$ and acenonitrile (7:3), for $10 \mathrm{~min}$. Volume injected was $20 \mu \mathrm{l}$ with a flow rate of $1 \mathrm{ml} \mathrm{min}{ }^{-1}$. UV detection was done at $238 \mathrm{~nm}$ and the absorption espectrum of each peak was analysed over the range of 190$300 \mathrm{~nm}$ (Freitas de Magalhaes et al. 2001).

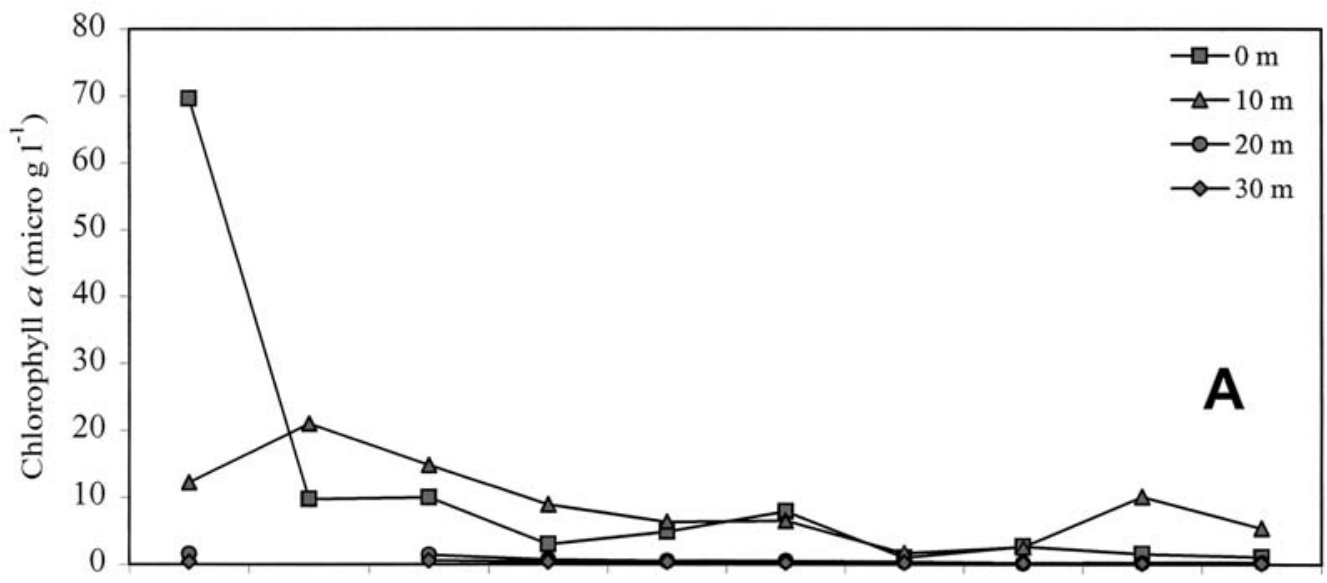

May 17 May 19 May 22 May 25 May 29 June $1 \quad$ June 8 June 15 June 22 June 29 2000

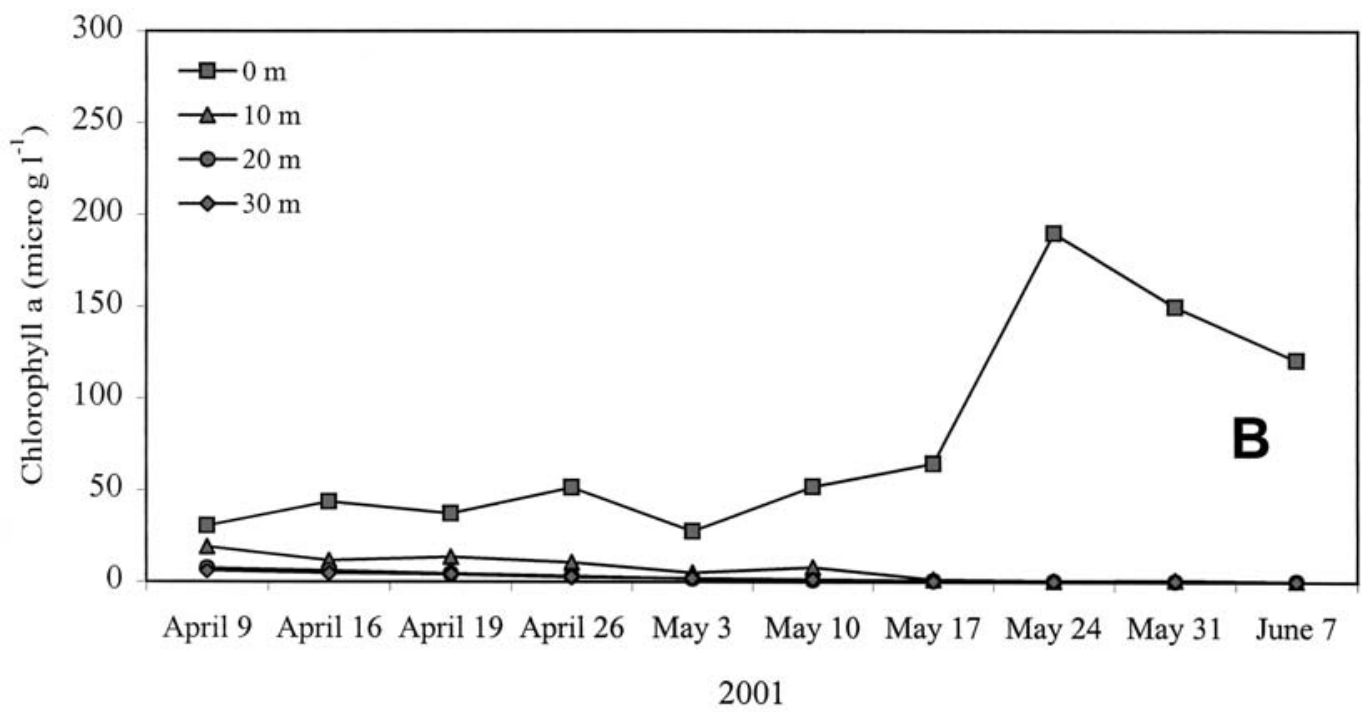

Figure 2. Vertical distribution of chlorophyll $a\left(\mathrm{~g} \mathrm{l}^{-1}\right)$ in El Atazar reservoir during the spring of 2000 and 2001. Distribución vertical de clorofila a $\left(\mu \mathrm{g} \mathrm{l}^{-1}\right)$ en el embalse de El Atazar durante la primavera de 2000 y 2001. 

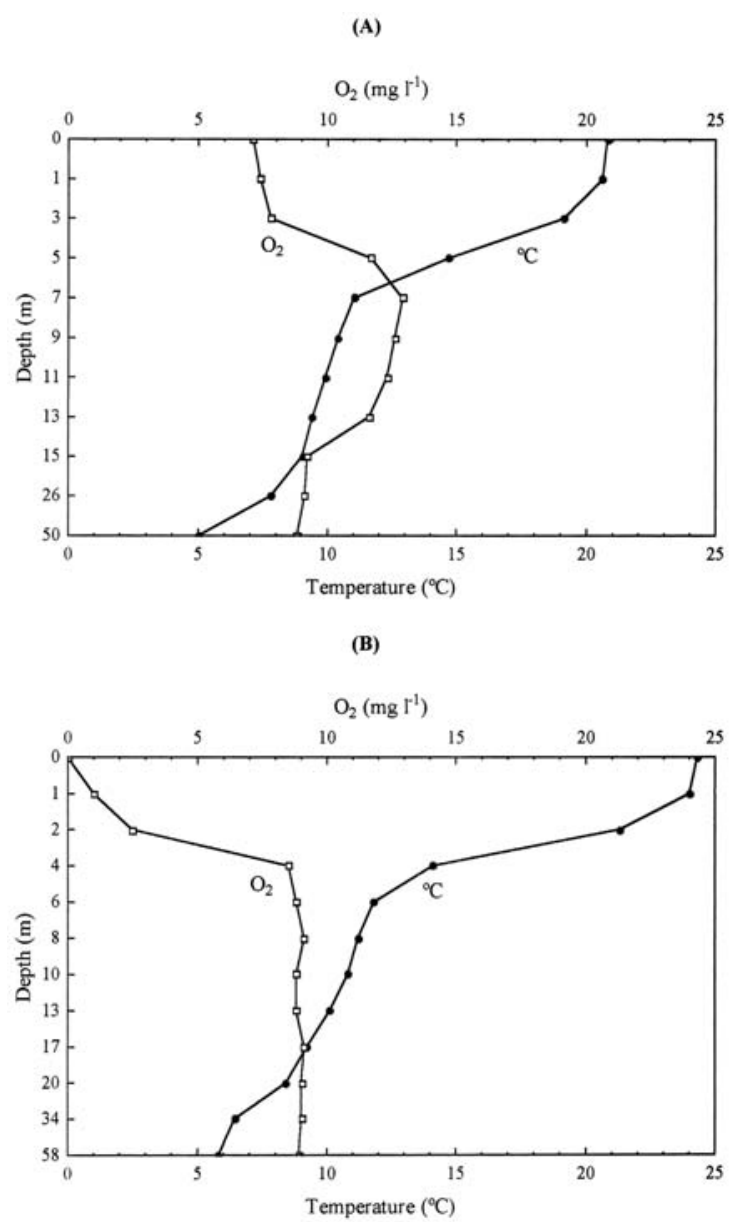

Figure 3. Hydrographical conditions (closed circles: water temperature; open squares: dissolved oxygen) of El Atazar reservoir during the bloom of P. rubescens in (A) June 12000 and (B) May 31 2001. Condiciones hidrográficas (círculos rellenos: temperatura del agua; cuadrados vacios: oxígeno disuelto) del embalse de El Atazar durante la proliferación de P. rubescens en (A) 1 de junio de 2000 y (B) 31 de mayo de 2001.

\section{RESULTS}

During the spring of 2000 and 2001 a surface bloom of $P$. rubescens was reported in El Atazar, an oligo-mesotrophic reservoir from central Spain. These blooms were firstly associated with the beginning of the thermal stratification of the reservoir. The spring rainfall in the area was higher than usual during those years, thus increasing the run-off of nutrients into the catchment. Moreover, rainfall events were alternated with exceptionally warm weather conditions, resulting in a sharp increase of water temperature and the onset of the stratification process in the reservoir.

The bloom of the year 2000 took place in the epilimnion from mid-May until the beginning of June, which caused high levels of chlorophyll $a\left(69.6 \mu \mathrm{g} \mathrm{l}^{-1}\right.$ during the peak of the bloom) (Figs. 1 and 2). This was joined with high $\mathrm{pH}$ values (mean $\mathrm{pH}, 9.2 \pm 0.2$ ) and oxygen saturation (mean $\mathrm{O}_{2}$ saturation, $133.9 \pm 4.3 \%$ ). Then, the red layer due to $P$. rubescens moved downwards to $5-10 \mathrm{~m}$ where it remained during the summer. The chlorophyll $a$ values rapidly decreased and mainly occurred at $5-10 \mathrm{~m}$ (mean Chl $a, 11.0 \pm 5.3 \mu^{g^{-1}}$ ) (Fig. 2). Below $10 \mathrm{~m}$ the water was relatively clear.

In spring 2001 the bloom was more intensive than the year before and lasted for a longer period (April to June). By the end of May the bloom reached a peak, which corresponded to a sharp increase in chlorophyll $a$ (mean Chl $a$, 153.7 $\pm 34.6 \mu \mathrm{g} \mathrm{l}^{-1}$ ) (Fig. 1 and 2), ammonia (mean $\mathrm{NH}_{4}^{+}, 1.1 \pm 0.2 \mathrm{mg} \mathrm{l}^{-1}$ ) and nitrite (mean $\left.\mathrm{NO}_{2}{ }^{-}, 0.003 \pm 0.001 \mathrm{mg} \mathrm{l}^{-1}\right)$ concentrations, as well as to a drop in dissolved oxygen which reached levels of $0 \mathrm{mg} \mathrm{l}^{-1}$ (Fig. 3). In addition, a substantial increase of surface water temperature was detected both years in the reservoir during the bloom (Figs. 3 and 4).

The data on water quality showed an increment of microcystin levels in the surface of the reservoir just after the beginning of the bloom in 2000 (Fig. 1). During the spring of 2001, MCYST concentrations in the surface were fluctuating and reached peaks above $1 \mu \mathrm{g} \mathrm{l}^{-1}$, whereas in 2000 MCYST were below this value except for the last 15 days of May.

The HPLC-mass spectrometer results indicated that only one sample of fish liver from the reservoir contained low amounts of molecules with molecular weight typical for the microcystins (mw 1024). The rest of samples did not contain microcystins of that mass. If at all, there were only very low concentrations of microcystins in the liver extracts from El Atazar. 


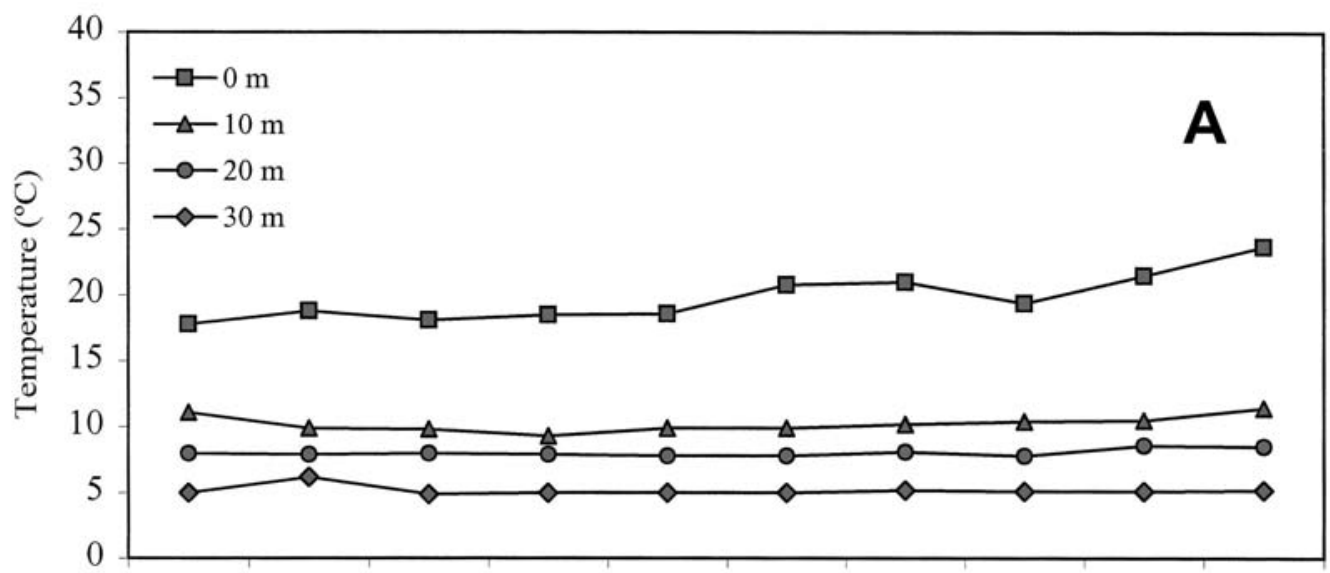

May 17 May 19 May 22 May 25 May 29 June 1 June 8 June 15 June 22 June 29

2000

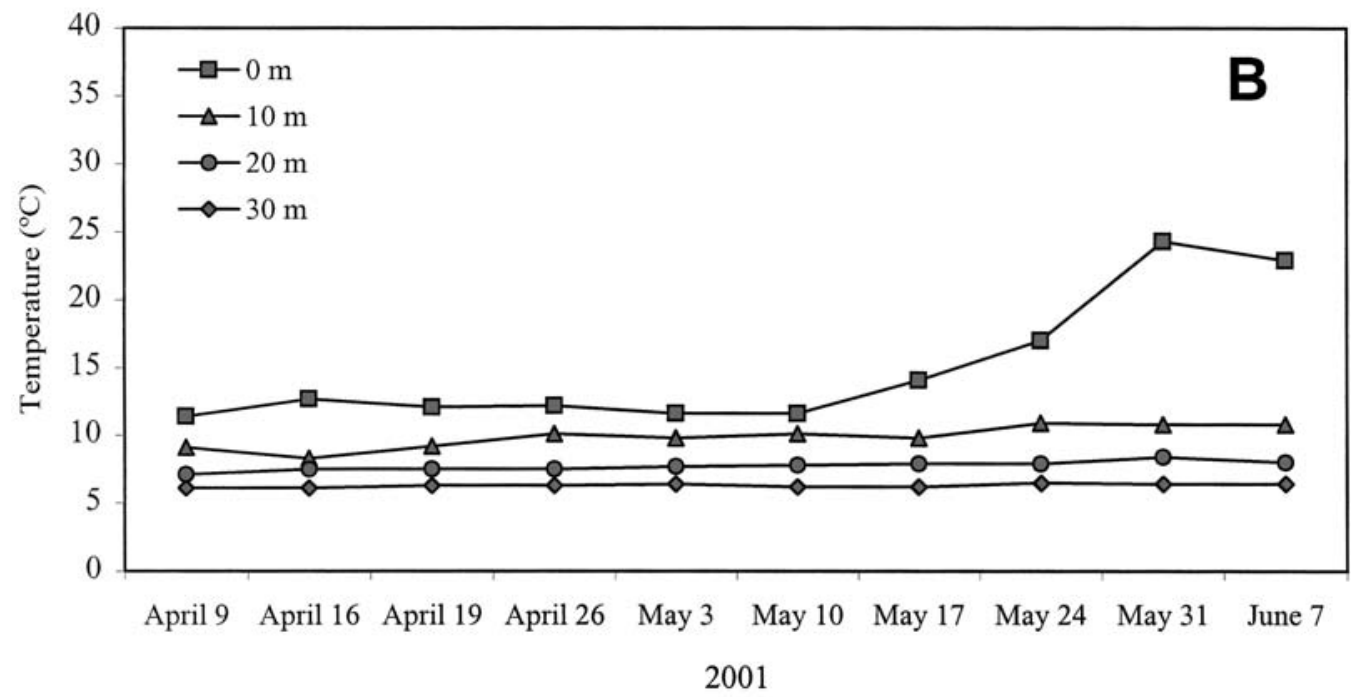

Figure 4. Vertical distribution of temperature $\left({ }^{\circ} \mathrm{C}\right)$ in El Atazar reservoir during the spring of 2000 and 2001.Distribución vertical de la temperatura $\left({ }^{\circ} \mathrm{C}\right)$ en el embalse de El Atazar durante la primavera de 2000 y 2001.

Liver sections revealed that $93 \%$ of the fish affected by the bloom had pigmented macrophage aggregates (MAs), which were not observed in the liver of control fish (Fig. 5). The mean number of MAs per specimen showed a large variability among samples, ranging from 0 to 131.2 (mean,
$29.6 \pm 33.0$ ) (Table 1). The distribution of MAs within the liver tissue was highly heterogeneous. Thus, the mean coefficient of variation $(\mathrm{CV}, \%)$ within each sample ranged between 14 and $88 \%$ (mean, 38.2 20.8 ) (Table 1). No other histopathological abnormalities were found in the liver. 
Table 1. Average number $( \pm \mathrm{SD})$, range and coefficient of variation $(\mathrm{CV}, \%)$ of pigmented macrophage aggregates (MAs) per individual found within the histological sections of liver from fish captured in El Atazar reservoir during the 2001 bloom. Número medio $( \pm S D$ ), rango y coeficiente de variación ( $\mathrm{CV}, \%)$ de centros melanomacrofágicos (MAs) por individuo encontrado en las preparaciones histológicas de tejido hepático de peces capturados en el embalse de El Atazar durante la proliferación de 2001.

\begin{tabular}{|c|c|c|}
\hline Mean \pm SD & Range & CV (\%) \\
\hline $1.2 \pm 1.0$ & $0-3$ & 88.3 \\
\hline $1.5 \pm 1.3$ & $0-3$ & 87.6 \\
\hline $4.3 \pm 2.2$ & $2-7$ & 51.4 \\
\hline $9.9 \pm 4.9$ & $8-18$ & 49.1 \\
\hline $11.7 \pm 4.8$ & $9-16$ & 41.2 \\
\hline $11.8 \pm 6.0$ & $3-18$ & 50.8 \\
\hline $12.0 \pm 8.8$ & $9-15$ & 73.0 \\
\hline $14.8 \pm 5.3$ & $10-23$ & 35.9 \\
\hline $15.2 \pm 4.6$ & $9-21$ & 30.5 \\
\hline $16.0 \pm 7.8$ & $12-20$ & 48.7 \\
\hline $19.4 \pm 5.0$ & $17-26$ & 25.9 \\
\hline $20.0 \pm 7.4$ & $13-27$ & 36.9 \\
\hline $20.4 \pm 12.6$ & $11-31$ & 61.7 \\
\hline $20.7 \pm 6.2$ & $14-27$ & 29.8 \\
\hline $21.2 \pm 4.0$ & $18-24$ & 18.8 \\
\hline $23.5 \pm 9.1$ & $12-31$ & 38.7 \\
\hline $23.8 \pm 9.4$ & $17-33$ & 39.7 \\
\hline $25.3 \pm 6.3$ & $13-30$ & 24.9 \\
\hline $26.9 \pm 5.5$ & $22-34$ & 20.5 \\
\hline $31.5 \pm 6.9$ & $25-39$ & 21.9 \\
\hline $52.4 \pm 7.5$ & $48-58$ & 14.4 \\
\hline $56.5 \pm 12.7$ & $46-70$ & 22.5 \\
\hline $59.6 \pm 9.6$ & $46-70$ & 16.1 \\
\hline $82.4 \pm 18.5$ & $53-91$ & 22.5 \\
\hline $116.9 \pm 21.7$ & $101-137$ & 18.6 \\
\hline $131.2 \pm 32.8$ & $100-161$ & 25.0 \\
\hline
\end{tabular}

\section{DISCUSSION}

The likely cause of $P$. rubescens blooms in El Atazar reservoir seemed to be the exceptional weather conditions during 2000 and 2001. First, the rapid increase of temperature during spring resulted in the reservoir stratification, which occurred just before the blooms. On the other hand, the increment of nutrients in the epilimnion caused by run-off during spring rainfall could have favoured cyanobacterial growth. The spring of 2001 was exceptionally rainy, which probably increased the nutrient levels of the surface layers in the reservoir and lead to the observed long-lasting bloom.

The occurrence of cyanobacterial blooms in two consecutive years suggests that $P$. rubescens remains latent at low densities until the conditions which favour its growth are present. At first, the cyanobacterial population probably displayed a rapid growth until it reached a threshold of maximum biomass, when nutrients presumably started to impoverish. As a result, massive death of cyanobacteria occurred, producing large amounts of dead organic matter and high MCYST concentrations in the reservoir. Also, the increment of suspended organic matter likely caused a sharp drop of dissolved oxygen and an increase of turbidity.

The accumulation and persistence of microcystins in fish liver during cyanobacterial bloom conditions have been recently reported by Freitas de Magalhaes et al. (2001). However, microcystins were not clearly found in the liver tissue of fish captured in the reservoir. This finding should not be considered as definitive since liver pathologies were detected in the fish studied. Thus, previous studies where fish were exposed to microcystins showed evidence of toxin accumulation and tissue damage in the liver (Phillips et al., 1985; Rahbergh et al., 1991; Tencalla et al., 1994; Carbis et al., 1996; Williams et al., 1997a; Fischer \& Dietrich, 2000). Freitas de Magalhaes et al. (2001) suggested that the method used in the present study for toxin extraction clearly underestimates microcystins concentration in the liver. Likewise, Williams et al. $(1997 \mathrm{a}, \mathrm{b})$ found that only $24 \%$ of the total microcystins from fish liver was extractable with methanol. On the other hand, several studies have shown that microcystins can be excreted rapidly (Eriksson et al., 1989; Robinson et al., 1991; Vasconcelos, 1995). Additionally, toxins could be metabolised to a less toxic compound through a detoxification system, as suggested by Wiegand et al. (1999) and Freitas de Magalhaes et al. (2001). 
(A)

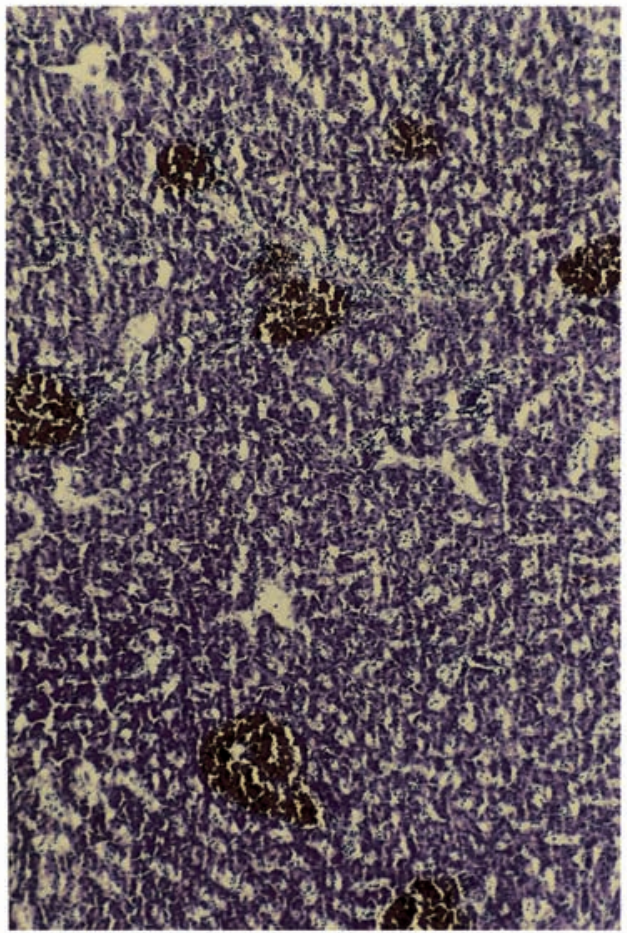

(B)

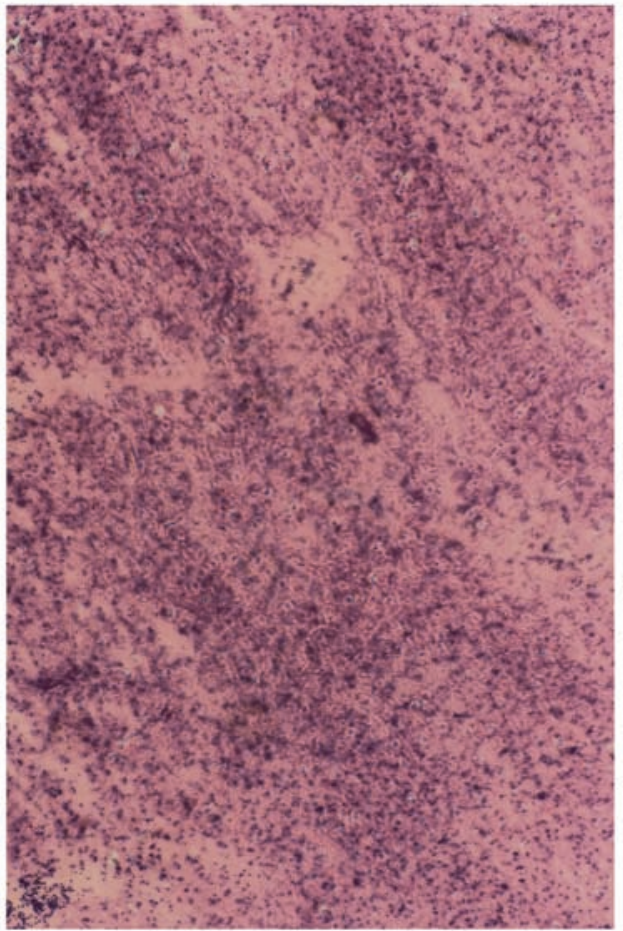

Figure 5. Histological sections of liver from fish (Barbus bocagei) captured in (A) El Atazar reservoir, showing several pigmented macrophage aggregates, and (B) River Madarquillos (reference area), showing a normal liver of control fish (H\&E, x10). Preparaciones histológicas de tejido hepático de peces (Barbus bocagei) capturados en (A) Embalse de El Atazar, donde se observan varios centros melanomacrofágicos, y (B) Río Madarquillos (área de referencia), donde se observa un hígado normal de peces utilizados como control (H\&E, x10).

The liver pathology found in the present study has similarities to the hepatic changes observed in fish from contaminated sites elsewhere (Ericson et al., 1999; Davis et al., 1999; Marty et al., 1999). Hence, the presence of pigmented macrophage aggregates in liver tissue samples from fish captured in the reservoir indicates that the hepatic pathology may be resulted from the direct ingestion or absorption of hepatotoxins from the water. The macrophage aggregates are usually found in kidney and spleen of teleost fish, but they can also appear in the liver as a result of certain pathologies (Wolke, 1992; A. Zapata, personal communication). The general function of MAs is the centralisation of foreign materials and cellular debris for destruction, detoxification or recycling (Vogelbein et al., 1987; Wolke, 1992; Zapata et al., 1996). Moreover, MAs are repositories of pigments that likely reflect previous tissue injury with accumulation of membrane breakdown products (Davis et al., 1999). Many factors are known to affect the accumulation and/or proliferation of MAs, including nutritional status (Agius \& Roberts, 1981) and infectious diseases (Herráez \& Zapata, 1987; Vogelbein et al., 1987). Further, MAs are known to change in number, size and pigment content in relation to fish health and environmental degradation (Wolke, 1992; Fournie et al., 2001). Therefore, some authors (Wolke, 1992; Fournie et al., 2001) have indicated that MAs can be used as histopathological 
bioindicators to monitor fish health and environmental quality. Moreover, the use of MAs as environmental biomarkers has been extensively documented during the last decades (e.g. Barker et al., 1994; Blazer et al., 1987,1994; Khan et al., 1994; Couillard \& Hodson, 1996).

In conclusion, the present study has shown that fish affected by the cyanobacterial bloom exhibited a liver pathology probably due to exposure to hepatotoxins. However, further research using electron microscopy techniques is needed to identify the accumulated pigments within the MAs. This could give an insight into the pathogenesis for the cyanobacteria-associated liver pathology. Additionally, alternative extraction methods are needed to improve the detection and quantification of toxins in the liver tissue, although an efficient liver detoxification can reduce the accumulated amount.

\section{ACKNOWLEDGEMENTS}

This study was supported by IMIA through a research project (FPE-01-1). The Department of Cell Biology of the Complutense University of Madrid kindly helped us with the histological analyses. We are also grateful to the Department of Biology of the Autónoma University of Madrid for their assistance in toxin extraction from fish liver analyses. We specially acknowledge the valuable suggestions and comments of A. Zapata, R. Pérez Gomariz and A. Quesada. We appreciate the collaboration of the water authorities from "Canal de Isabel II" in facilitating water quality data and the Regional Environmental Agency of Madrid in field work assistance.

\section{REFERENCES}

AGIUS, C. \& R. J. ROBERTS. 1981. Effects of starvation on the melano-macrophage centres in fish. J. Fish Biol., 19: 161-169.

AMERICAN PUBLIC HEALTH ASSOCIATION 1985. Standard Methods for the Examination of
Water and Wastewater. $16^{\text {th }}$ edition. Public Health Association, Washington.

BAGANZ, D., G. STAAKS \& C. STEINBERG. 1998. Impact of the cyanobacteria toxin, microcystin-LR, on the behavior of zebrafish, Danio rerio. Wat. Res., 32: 948-952.

BARKER, D. E., R. A. KHAN, E. M. LEE, R. G. HOOPER \& K. RYAN. 1994. Anomalies in sculpins (Myoxocephalus spp.) sampled near a pulp and paper mill. Arch. Environ. Contam. Toxicol., 26: 491-496.

BEATTIE, K. A., K. KAYA, T. SANO \& G. A. CODD. 1998. Three dehydrobutyrine (Dhb)-containing microcystins from the cyanobacterium Nostoc sp. Phytochemistry, 47: 1289-1292.

BERG, K., O. M. SKULBERG, R. SKULBERG, B. UNDERDAL \& T. WILLEN. 1986. Observations of toxic blue-green algae (cyanobacteria) in some Scandinavian lakes. Acta vet. Scand., 27: 440-452.

BLAZER, V. S., R. E. WOLKE, J. BROWN \& C. A. POWELL. 1987. Piscine macrophage aggregate parameters as health monitors: effect of age, sex, relative weight, season and site quality in largemouth bass (Micropterus salmoides). Aquat. Toxic., 10: 199-215.

BLAZER, V. S., D. E. FACEY, J. W. FOURNIE, L. A. COURTNEY \& J. K. SUMMERS. 1994. Macrophage aggregates as indicators of environmental stress. In: Modulators of fish immune responses, J.S. Stolen \& T.C. Fletcher (eds.), Vol. 1. SOS Publications, Fair Heaven, New Jersey.

BRUNO, D. W., G. DEAR \& D. D. SEATON. 1989. Mortality associated with phytoplankton blooms among farmed Atlantic salmon, Salmo salar L., in Scotland. Aquaculture, 78: 217-222.

BURY, N. R., G. FLIK, F. B. EDDY. \& G. A. CODD. 1996. The effects of cyanobacteria and the cyanobacterial toxin microcystin-LR on $\mathrm{Ca}^{++}$transport and $\mathrm{Na}^{+} / \mathrm{K}^{+}$- ATPase in Tilapia gills. J. Exp. Biol., 199:1319-1326.

CARBIS, C. R., J. A. SIMONS, G. F. MITCHELL, J. W. ANDERSON \& I. MCCAULEY. 1994. A biochemical profile for predicting the chronic exposure of sheep to Microcystis aeruginosa, an hepatotoxic species of blue-green alga. Res. Vet. Sci., 57: 310-316.

CARBIS, C. R., G. T. RAWLIN, G. F. MITCHELL, J. W. ANDERSON \& I. MCCAULEY. 1996. The histopathology of carp, Cyprinus carpio L., exposed to microcystins by gavage, immersion and intraperitoneal administration. J. Fish Dis., 19: 199-207. 
CARMICHAEL, W. W. 1992. Cyanobacteria secondary metabolites. The cyanotoxins. J. Appl. Bacteriol., 72: 445-459.

CHORUS, I. \& J. BARTRAM. (eds.) 1999. Toxic cyanobacteria in water. A guide to their public health consequences, monitoring and management. E \& FN Spon, London, 416 pp.

CHU, F. S., X. HUANG \& R. O. WEI. 1990. Enzyme-linked immunosorvent assay for microcystins in blue-green algal blooms. J. Off. Ana. Chem., 73: 451-456.

COUILLARD, C. M. \& P. V. HODSON. 1996. Pigmented macrophage aggregates: a toxic response in fish exposed to bleached-kraft mill effluent?. Environ. Toxicol. Chem., 15: 1844-1854.

DAVIS, C. R., G. D. MARTY, M. A. ADKISON, E. F. FREIBERG \& R. P. HEDRICK. 1999. Association of plasma IgM with body size, histopathologic changes, and plasma chemistries in adult Pacific herring Clupea pallasi. Dis. Aquat. Org., 38: 125-133.

DISBREY, B. D. \& J. H. RACK. 1970. Curtis's picro-ponceau stain for collagen and Mayers haematoxylin and eosin stain. In: Histological Laboratory Methods. E \& S Livingston (eds.): 93110. London.

ERICSON, G., B. LIEWENBORG, E. LINDESJÖÖ, C. NÄF \& L. BALK. 1999. DNA adducts in perch (Perca fluviatilis) from a creosote contaminated site in the River Angermanalven, Sweden. Aquat. Toxicol., 45: 181-193.

ERIKSSON, J. E., J. A. O. MERILUOTO \& T. LINDHOLM. 1986. Can cyanobacterial toxins accumulate in aquatic food chains? In: Perspectives in microbial ecology. F. Megusar \& M. Gantar (eds.): $655-658$. Proceedings of the $4^{\text {th }}$ International Symposium on Microbial Ecology, Slovene Society of Microbiology, Ljubliana.

ERIKSSON, J. E., J. A. O. MERILUOTO \& T. LINDHOLM. 1989. Accumulation of a peptide toxin from the cyanobacterium Oscillatoria agardhii in the freshwater mussel Anodonta cygnea. Hydrobiologia, 183: 211-216.

ERIKSSON, J. E., L. GRONBERG, S. NYGARD, J. P. SLOTTE \& J. A. O. MERILUOTO. 1990. Hepatocellular uptake of ${ }^{3} \mathrm{H}$-dihydromicrocystinLR, a cyclic peptide toxin. Biochim. Biophys. Acta, 1025: 60-66.

FALCONER, I. R., T. BUCKLEY \& M. T. RUNNEGAR. 1986. Biological half life, organ distribution and excretion of I-labelled toxic peptide from the blue-green alga Microcystis aeruginosa. Aust. J. Biol. Sci., 39: 17-21.

FISCHER, W. J. \& D. R. DIETRICH. 2000. Pathological and biochemical characterization of microcystin-induced hepatopancreas and kidney damage in carp (Cyprinus carpio). Toxicol. Appl. Pharmacol., 164: 73-81.

FOURNIE, J. W., J. K. SUMMERS, L. A. COURTNEY, V. D. ENGLE \& V. S. BLAZER. 2001. Utility of splenic macrophage aggregates as an indicator of fish exposure to degraded environments. J. Aquat. Anim. Health, 13: 105-116.

FREITAS DE MAGALHAES, V., R. MORAES SOARES \& S. M. F. O. AZEVEDO. 2001. Microcystin contamination in fish from the Jacarepaguá Lagoon (Rio de Janeiro, Brazil): ecological implication and human health risk. Toxicon, 39: 1077-1085.

GAETE, V., E. CANELO, N. LAGOS \& F. ZAMBRANO. 1994. Inhibitory effects of microcystis aeruginosa toxin on ion pumps of the gills of freshwater fish. Toxicon, 82: 121-127.

HERRÁEZ, M. P. \& A. G. ZAPATA. 1987. Trapping of intraperitoneal-injected Yersinia ruckeri in the lymphoid organs of Carassius auratus: the role of melano-macrophage centres. J. Fish Biol., 31: 235-237.

KHAN, R. A., D. E. BARKER, R. HOOPER, E. M. LEE, K. RYAN \& K. NAG. 1994. Histopathology in winter flounder (Pleuronectes americanus) living adjacent to a pulp and paper mill. Arch. Environ. Contam. Toxicol., 26: 95-102.

LEEUWANGH, P., F. I. KAPPERS, M. DEKKER \& W. KOERSELMAN. 1983. Toxicity of cyanobacteria in Dutch lakes and reservoirs. Aquat. Toxic., 4: 63-72.

LINDHOLM, T., J. E. ERIKSSON \& J. A. O. MERILUOTO. 1989. Toxic cyanobacteria and water quality problems-examples from a eutrophic lake on Aland, south west Finland. Wat. Res., 23: 481486.

MARTY, G. D., M. S. OKIHIRO, E. D. BROWN, D. HANES \& D. E. HINTON. 1999. Histopathology of adult Pacific herring in Prince William Sound, Alaska, after the Exxon Valdez oil spill. Can. J. Fish. Aquat. Sci., 56: 419-426.

MASON, C. F. 1991. Biology of freshwater pollution. $2^{\text {nd }}$ Edition. Longman Scientific \& Technical, Essex. 351 pp.

OBEREMM, A., J. FASTNER \& C. STEINBERG. 1997. Effects of microcystin-LR and cyanobacte- 
rial crude extracts on embryo-larval development of zebrafish (Danio rerio). Wat. Res., 31: 29182921.

OSTENSVIK, O., O. M. SKULBERG \& N. E. SOLI. 1981. Toxicity studies with blue-green algae from Norwegian inland waters. In: The water environment: algal toxins and health. W.W. Carmichael (ed.): 315-342. Plenum Press.

PAERL, H. W., R. S. FULTON III, P. H. MOISANDER \& J. DYBLE. 2001. Harmful freshwater algal blooms, with an emphasis on Cyanobacteria. Sci. World, 1: 76-113.

PHILLIPS, M. J., R. J. ROBERTS, J. A. STEWART \& G. A. CODD. 1985. The toxicity of the cyanobacterium Microcystis aeruginosa to rainbow trout, Salmo gairdneri Richardson. J. Fish Dis., 8: 339-334.

RAHBERGH, C. M. I., G. BYLUND \& J. E. ERIKSSON. 1991. Histopathological effect of microcystin-LR a cyclic polypeptide from the cyanobacterium Microcystis aeruginosa on common carp (Cyprinus carpio L.). Aquat. Tox., 20: 131-146.

ROBARTS, R. D. \& T. ZOHARY. 1987. Temperature effects on photosynthetic capacity, respiration, and growth rates of bloom forming cyanobacteria. N. Z. J. Freshwat. Res., 21:391-399.

ROBINSON, N. A., J. G. PACE, C. F. MATSON, G. A. MIURA \& W. B. LAWRENCE. 1991. Tissue distribution, excretion and hepatic biotransformation of microcystin-LR in mice. J. Pharmacol. Exper. Therap., 256: 176-182.

RODGER, H. D., T. TURBULL, C. EDWARDS \& C. CODD. 1994. Cyanobacterial (blue-green algal) bloom associated pathology in brown trout Salmo trutta L. in Loch Leven, Scotland. J. Fish Dis., 17: 177-181.

RUNNEGAR, M. T., I. R. FALCONER, T. BUCKLEY \& A. R. B. JACKSON. 1986 Lethal potency and tissue distribution of ${ }^{125}$ I-labelled toxic peptides from the blue-green alga Microcystis aeruginosa. Toxicon, 24: 506-509.

RUNNEGAR, M. T., S. KONG \& N. BERNDT. 1993. Protein phosphatase inhibition and in vivo hepatotoxicity of microcystins. Am. J. Physiol., 265: 224-230.

SKULBERG, O. M., G. A. CODD \& W. W. CARMICHAEL. 1984. Toxic blue-green algal blooms in Europe. A growing problem. Ambio, 13: 244-247.

SKULBERG, O. M., W. W. CARMICHAEL, G. A. CODD \& R. SKULBERG. 1993. Taxonomy of toxic cyanophyaceae. In: Algal toxins in seafood and drinking water. I.R. Falconer (ed.): 145-164. Academic Press, London.

SMITH, R. V. 1977. Domestic and agricultural contributions to the inputs of phosphorous and nitrogen to Lough Neagh. Water Res., 11: 453-459.

TENCALLA, F., D. DIETRICH \& C. SCHLATTER. 1994. Toxicity of Mycrocystis aeruginosa peptide toxins to yearling rainbow trout (Oncorhynchus mykiss). Aquat. Toxic., 30: 215-224.

THOSTRUP, L. \& K. CHRISTOFFERSEN. 1999. Accumulation of microcystins in Daphnia magma feeding on toxic Microcystis. Arch. Hydrobiol., 145: 447-467.

VASCONCELOS, V. M. 1994. Toxic cyanobacteria (blue-green algae) in Portuguese fresh waters. Arch. Hydrobiol., 130: 439-451.

VASCONCELOS, V. M. 1995. Uptake and depuration of the heptapeptide toxin mycrocistin-LR in Mytilus galloprovincialis. Aquat. Toxic., 32: 227237.

VOGELBEIN, W. K., J. W. FOURNIE \& R. M. OVERSTREET. 1987. Sequential development and morphology of experimentally induced hepatic melanomacrophage centres in Rivulus marmoratus. J. Fish Biol., 31: 145-153.

WIEGAND, C., S. PFLUGMACHER, A. OBEREMM, N. MEEMS, K. A. BEATTIE, C. E. W. STEINBERG \& G. A. CODD. 1999. Uptake and effects of microcystin-LR on detoxication enzymes of early life stages of zebrafish (Danio rerio). Environ. Toxicol., 14: 89-95.

WILLIAMS, D. E., M. CRAIG, S. C. DAWE, M. C. KENT, C. F. B. HOLMES \& R. J. ANDERSON. 1997a. Evidence for a covalently bound form of microcystin-LR in salmon larvae and dungness crab larvae. Chem. Res. Toxicol., 10: 463-469.

WILLIAMS, D. E., M. CRAIG, S. C. DAWE, M. L. M. L. KENT, R. J. ANDERSEN \& C. F. B. HOLMES. 1997b. ${ }^{14} \mathrm{C}$ labeled microcystin-LR administrated to Atlantic salmon via intraperitoneal injection provides in vivo evidence for covalent binding of microcystin-LR in salmon livers. Toxicon, 35: 985-989.

WOLKE, R. E. 1992. Piscine Macrophage Aggregates: A review. Ann. Rev. Fish Dis., 2: 91108.

ZAPATA, A. G., A. CHIBÁ \& A. VARAS. 1996. Cells and tissues of the immune system of fish. In: The fish immune system. Organism, pathogen, and environment. G. Iwama \& T. Nakanishi (eds.): 1-62. Academic Press, San Diego, California. 
